\title{
Protective Effects of Quercetin on Intestinal Damage Caused by lonizing Radiation
}

\author{
Radyasyona Bağlı Intestinal Hasarda Quercetin'in Koruyucu Etkisi \\ ๑ Özcan Pişkin, ๑ Bengü Gülhan Aydın, ๑ Yılmaz Baş, ๑ Kemal Karakaya** \\ ๑ Murat Can***, ๑ Özlem Elmas****, ๑ Mustafa Çağatay Büyükuysal*****
}

Bülent Ecevit University Faculty of Medicine, Department of Anesthesiology and Reanimation, Zonguldak, Turkey

*Hitit University Faculty of Medicine, Department of Pathology, Çorum, Turkey

**Bülent Ecevit University Faculty of Medicine, Department of General Surgery, Zonguldak, Turkey

${ }^{* * *}$ Bülent Ecevit University Faculty of Medicine, Department of Biochemistry, Zonguldak, Turkey

$* * * *$ Bülent Ecevit University Faculty of Medicine, Department of Radiation Oncology, Zonguldak, Turkey

$* * * * *$ Bülent Ecevit University Faculty of Medicine, Department of Biostatistics, Zonguldak, Turkey

\section{Abstract}

Aim: The aim of this study was to evaluate the protective use of quercetin in a rat model of radiation-induced enteritis and colitis.

Methods: Twenty four adult rats were randomly divided into four groups. Group SHAM was given only physiological saline, group QUER was given quercetin $50 \mathrm{mg} / \mathrm{kg}$ for 15 days, group RAD was given only irradiation and group QUER+RAD was given quercetin $50 \mathrm{mg} / \mathrm{kg}$, and then irradiated. Twenty four hours after the exposure to radiation, all rats were euthanized for the evaluation of the ileum and colon morphology and biochemical measurements.

Results: Compared with the SHAM group, the serum malondialdehyde (MDA) level was significantly higher in group RAD $(p=0.004)$ and was significantly decreased in group QUER+RAD ( $p=0.015)$. The MDA levels in the ileum and colon tissues were significantly higher in group $\operatorname{RAD}(p=0.004$ and $p=0.002$, respectively), while treatment with quercetin significantly reduced lipid peroxidation in both tissues in group QUER+RAD ( $p=0.015$ and $p=0.009$, respectively). Compared with the control group, the serum total antioxidant status (TAS) level was significantly lower in Group RAD ( $p=0.002)$ and was significantly increased in group QUER+RAD ( $p=0.009)$. TAS in the ileum and colon tissues were significantly lower in group RAD ( $p=0.002$ and $p=0.002$ ) and were significantly higher in both tissues in group QUER+RAD ( $p=0.002$ and $p=0.002$, respectively).

Conclusion: This study confirmed that, in the model of radiationinduced ileitis and colitis in rats, quercetin effectively decreased oxidative stress and inflammatory damage to both ileum and colon tissues.

Keywords: Quercetin, intestine damage, oxidative stress, radiation, rat
Öz

Amaç: Bu çalışmanın amacı rat modelinde radyasyona bağlı oluşan enterit ve kolit tedavisinde quercetin'in koruyucu rolünü değerlendirmektir.

Yöntemler: Yirmi dört yetişkin rat randomize olarak dört gruba ayrıldı. Group SHAM'a sadece salin, grup QUER'e 15 gün boyunca 50 mg/ kg quercetin, grup RAD'a sadece radyasyon ve grup QUER+RAD'a 15 gün boyunca $50 \mathrm{mg} / \mathrm{kg}$ quercetin ardından radyasyon uyguland. Radyasyon maruziyetinden 24 saat sonra ileum ve kolon morfolojisi ve biyokimyasal parametrelerin değerlendirilmesi için ratlara ötenazi uygulandı.

Bulgular: SHAM grubuyla karşılaştırılığında, serum malondialdehit (MDA) seviyesi grup RAD'da istatistiksel olarak anlamlı derecede yüksek $(p=0,004)$ ve grup QUER+RAD'da düşük bulundu $(p=0,015)$. ileum ve kolon dokularındaki MDA seviyesi grup RAD'da anlamlı olarak daha yüksek (sırasıyla; $p=0,004$ ve $p=0,002$ ) idi. Grup QUER+RAD'da ise her iki dokuda azalmış olarak bulundu (sırasıyla; $p=0,015$ ve $p=0,009$ ). Kontrol grubuyla karşılaştırıldığı zaman, serum total antioksidan kapasite (TAK) seviyesi grup RAD'da istatistiksel olarak anlamlı derecede düşük $(p=0,002)$ ve grup QUER+RAD'da ise yüksek bulundu $(p=0,009)$. ileum ve kolon dokularındaki TAK seviyesi grup RAD'da istatistiksel olarak anlamlı derecede düşük iken (sırasıyla; $p=0,002$ ve $p=0,002$ ), grup QUER+RAD'da ise her iki dokuda da anlamlı derecede yüksek bulundu (sırasılya; $p=0,002$ ve $p=0,002$ ).

Sonuç: Bu çalışma, ratlarda oluşturulan radyasyona bağlı ileit ve kolit modelinde quercetin'in, hem ileum hem de kolon dokularına oksidatif stres ve enflamatuvar hasarı etkili bir şekilde azalttığını doğrulamıştır.

Anahtar Sözcükler: Quercetin, intestinal hasar, oksidatif stres, radyasyon, rat
Address for Correspondence/Yazışma Adresi: Özcan Pişkin

Bülent Ecevit University Faculty of Medicine, Department of Anesthesiology and Reanimation, Zonguldak, Turkey

Phone: +90 5054562449 E-mail: drozcanp@gmail.com ORCID ID: orcid.org/0000-0003-3538-0317 Received/Geliş Tarihi: 16 May 2017 Accepted/Kabul Tarihi: 24 August 2017
${ }^{1}$ Copyright 2018 by The Medical Bulletin of University of Health Sciences Haseki Training and Research Hospital
The Medical Bulletin of Haseki published by Galenos Yayinevi.

${ }^{\circledR}$ Telif Hakkı 2018 Sağlık Bilimleri Üniversitesi Haseki Eğitim ve Araştırma Hastanesi Haseki Tıp Bülteni, Galenos Yayınevi tarafindan basılmışıı. 


\section{Introduction}

Radiotherapy (RT) has an important place in the treatment of abdominopelvic cancers (1). The most important reason for limiting the RT dosage is that, during $\mathrm{RT}$, normal tissues are exposed to radiation along with the cancerous tissues $(2,3)$. After the bone marrow, the gastrointestinal system (GIS) is the region most sensitive to the effects of radiation because of its rapid mitotic activity and, following RT, radiation-induced enteritis and/ or colitis generally occur $(4,5)$. During radiation exposure, inflammatory cells are activated, causing mucosal damage. Several studies have shown that, in the pathology associated with RT, there is crypt cell destruction along the GIS tract, a decrease in the number and size of villous structures, and an increase in ulcerative and necrotic areas (6-8).

Although the mechanism behind the above phenomena is not yet fully understood, reactive oxygen species that emerge in the mitochondria during radiation are thought to be harmful to proteins, lipids, and nucleic acids $(6,9)$. In previous studies, chemical agents and oral nutritional supplements were used to reduce these complications associated with $\mathrm{RT}(1,3,7,10,11)$.

In vitro studies have shown flavonoids to have antiinflammatory and anti-oxidant properties in a wide range of biological and pharmacological systems $(12,13)$. Animal experimental studies have shown that the antiinflammatory effects of flavonoids are mediated through the inhibition of reactive oxygen or nitrogen compounds (14). Flavonoids may also show anti-inflammatory effects by inhibiting pro-inflammatory activities of enzymes such as cyclooxygenase, lipoxygenase, and inducible nitric oxide synthase (14).

Quercetin is a potent anti-oxidant and anti-inflammatory flavonoid, which is found abundantly in onions, broccoli, apples, grapes, wine, tea, and leafy green vegetables (15). It shows anti-ulcerative, anti-hypertensive, anti-depressant, and anti-inflammatory properties with effects on various cellular pathways (16). In addition to platelet aggregation inhibition, it also shows protective effects against oxidative damage and cytotoxicity (17). The aim of this study was to evaluate the protective use of quercetin in a rat model of radiation-induced enteritis and colitis.

\section{Methods}

\section{Chemicals}

Quercetin was purchased from Sigma-Aldrich Co. (St. Louis, MO, USA).

\section{Animals and Experimental Protocol}

Approval for this study was granted by the Animal Experiments Local Ethics Committee of Zonguldak (Turkey)
Bülent Ecevit University Faculty of Medicine (2016-4106/10). All procedures conformed with international guidelines on the care and use of experimental animals.

In total, 24 adult male Wistar albino rats, each weighing 300-350 g, were divided randomly into four groups. The rats were obtained from the Bülent Ecevit University Experimental Animals Research Unit. All were fed with standard rat pellets and housed in temperature- and humidity-controlled $\left(23 \pm 1^{\circ} \mathrm{C}\right.$ and $55 \%$ relative humidity) rooms that were lit on a 12/12-h light/dark basis until the day of the experiment.

Group SHAM was given only physiological saline (PS) (no RT; $\mathrm{n}=6$ ), group QUER was given quercetin at $50 \mathrm{mg} /$ $\mathrm{kg}$ body weight (BW) daily in distilled water and 0.25 $\mathrm{mL}$ of PS for 15 days (no RT; $n=6$ ), group RAD was given only radiation ( $R T ; n=6)$, and group QUER+RAD was given quercetin at $50 \mathrm{mg} / \mathrm{kg}$ BW daily in distilled water and $0.25 \mathrm{~mL}$ of PS for 15 days and then irradiated (RT+QUER; $\mathrm{n}=6)$. At the end of 15 days, the animals in groups RAD and QUER+RAD were exposed to a dose of $10 \mathrm{~Gy}$ to the abdominopelvic region. All rats were decapitated $24 \mathrm{~h}$ after exposure to radiation.

\section{Irradiation}

The experimental model of anaesthetised rats for irradiation was used, as described by Gultekin et al. (18). The animals in groups RAD and QUER+RAD were anaesthetised with an intraperitoneal injection of $100 \mathrm{mg} /$ $\mathrm{kg}$ ketamine, then four rats in the prone position were administered a single non-lethal dose of 10 Gy using a 6-MV linear accelerator at a dose rate of $\sim 1 \mathrm{~Gy} / \mathrm{min}$ with the source axis distance (SAD) technique and a 1.0-cm bolus material on the surface. A computed tomography simulation of a rat was performed with 1-mm slices, and a dose calculation was performed with the Eclipse treatment planning system (version 8.9; Varian Medical Systems, Palo Alto, CA, USA). The animals were returned to their home cages following irradiation. Control animals were anaesthetised but not exposed to radiation. All irradiations were performed between 08:00 and 09:30 A.M.

\section{Chemical Analysis}

Tissue samples were cut into small pieces and then homogenised in phosphate-buffered saline ( $\mathrm{pH}$ 7.4) using a glass-Teflon homogeniser (Ultra Turrax IKA T18 Basic) for 2 min at $5.000 \mathrm{rpm}$. The homogenate was then centrifuged $(5.000 \mathrm{~g}, 15 \mathrm{~min})$. The supernatant was used for the analysis. Serum and tissue levels of total antioxidant status (TAS) and malondialdehyde (MDA) were measured using a colorimetric method with a TAS and MDA kit (Oxford Biomedical Research, Oxford, USA) in accordance with the manufacturer's protocol. 


\section{Histopathology}

Histological examinations of the samples collected from the colon and ileum were conducted using a modified version of the method described by Odabasi et al. (5) and Howarth et al. (19). Microscopic assessment of each specimen was performed to determine the mucosal, submucosal, and muscularis externa thickness in the ileum and colon. Using a $\times 100$ eyepiece micrometer, measurements were taken of the mucosal, submucosal, and muscularis externa thicknesses at 20 representative sites.

\section{Histopathology of the lleum}

For the examination of the ileum in the four groups, thicknesses of the submucosa, muscularis externa, and mucosa were measured. Then, the ileum and colon histopathology was graded with a modified version of the technique described by Howarth et al. (19) and the severity of the damage was determined using the damage severity score (DSS). The four groups were examined in terms of 12 parameters, defined as villus tip erosion, severity of neutrophil leukocyte reaction in the lamina propria, severity of eosinophil reaction in the lamina propria, severity of nuclear changes, severity of fibrinoid changes in the vascular wall, severity of changes in fibroblasts in the mucosa, severity of brush border damage, severity of lymphocyte reaction, villus tip fusion, mitosis, crypt abscess, blood vessel or lymphatic dilation, and ulcer form. Each criterion was scored from 0 to 3 ( $0=$ normal, $1=$ mild damage, $2=$ moderate damage, $3=$ severe damage) in each area for a maximum of 36 points.

\section{Histopathology of the Colon}

As in the ileum, the submucosa, muscularis externa, and mucosal thicknesses were measured for the colon. Colon histopathology was graded using the same method and the severity of damage was determined using the DSS (19). The four groups were examined in terms of 11 parameters, defined as colon surface epithelial erosion, severity of neutrophil leukocyte reaction in the lamina propria, severity of eosinophil reaction in the lamina propria, severity of nuclear changes, severity of fibrinoid changes in the vascular wall, severity of changes in fibroblasts in the mucosa, severity of lymphocyte reaction, mitosis, crypt abscess, blood vessel or lymphatic dilation, and ulcer form. Each area was scored with a maximum of 33 points.

\section{Statistical Analysis}

All analyses were performed with the "R" software (version 3.3.2). Descriptive statistics were stated as mean \pm standard deviation, median, minimum, and maximum values for continuous variables. Conformity to a normal distribution was assessed with the Shapiro-Wilk test. Differences between the four groups were evaluated with ANOVA and the Kruskal-Wallis test. Tukey and Bonferronicorrected Mann-Whitney $U$ tests were used as post hoc tests for ANOVA and the Kruskal-Wallis test, respectively. For all statistical comparisons, a value of $p$ less than 0.05 was considered to indicate statistical significance.

\section{Results}

The results of the biochemical assessments of peroxidation and anti-oxidant capacity parameters are shown in Tables 1 and 2.

\section{Biochemical Parameters}

MDA is associated with lipid peroxidation. Compared with the SHAM group, the serum MDA level was significantly higher in group RAD $(p=0.004)$ and was significantly decreased in group QUER+RAD $(p=0.015)$ (Table 1). The MDA levels in the ileum and colon tissues were significantly higher in group RAD ( $p=0.004$ and $p=0.002$, respectively) (Table 1 ) (Figure 1), while treatment with quercetin significantly reduced lipid peroxidation in both tissues in group QUER+RAD ( $p=0.015$ and $p=0.009$, respectively) (Table 1) (Figure 1).

TAS activity indicates anti-oxidant capacity. Compared with the control group, the serum TAS level was significantly lower in group $\operatorname{RAD}(p=0.002)$ and was significantly increased in group QUER+RAD $(p=0.009)$ (Table 2). TAS levels in the ileum and colon tissues were

\begin{tabular}{|l|l|l|l|}
\hline \multicolumn{1}{|l|}{ Table 1. Malondialdehyde levels of experimental groups } \\
\hline & $\begin{array}{l}\text { Ileum } \\
(\mathbf{n m o l} / \mathbf{g} \text { wet tissue) }\end{array}$ & $\begin{array}{l}\text { Colon } \\
(\mathbf{n m o l} / \mathbf{g} \text { wet tissue) }\end{array}$ & $\begin{array}{l}\text { Plasma } \\
(\boldsymbol{\mu m o l} / \mathbf{L})\end{array}$ \\
\hline Group SHAM & $77.15(27.60-85.70)^{\mathrm{a}}$ & $40.85(14.30-56.50)^{\mathrm{a}}$ & $3.51(3.10-5.32)^{\mathrm{a}, \mathrm{b}}$ \\
\hline Group QUER & $96.10(32.20-125.0)^{\mathrm{d}}$ & $56.05(43.10-85.70)^{\mathrm{c}}$ & $4.36(3.10-6.10)^{\mathrm{c}}$ \\
\hline Group RAD & $145.3(85.0-90.0)^{\mathrm{a}, \mathrm{e}}$ & $104.75(70.1-140.0)^{\mathrm{a}, \mathrm{c}, \mathrm{e}}$ & $6.83(4.23-8.37)^{\mathrm{a}, \mathrm{c}, \mathrm{e}}$ \\
\hline Group QUER+RAD & $65.05(42.1-134.0)^{\mathrm{d}, \mathrm{e}}$ & $63.5(26.2-166.8)^{\mathrm{e}}$ & $5.19(3.50-5.41)^{\mathrm{b}, \mathrm{e}}$ \\
\hline p value & 0.022 & 0.005 & 0.011 \\
\hline $\begin{array}{l}\text { QUER: Quercetin, RAD: Radiation } \\
\text { Values are reported as median (minimum and maximum value), }(\mathrm{n}=6) \\
\text { a,b,c,d,: Statistically significant with Bonferonni corrected Mann-Whitney U test }\end{array}$ & \\
\hline
\end{tabular}


significantly lower in group RAD ( $p=0.002$ and $p=0.002$, respectively) (Table 2 ) (Figure 1 ) and were significantly higher in both tissues in group QUER+RAD ( $p=0.002$ and $\mathrm{p}=0.002$, respectively) (Table 2) (Figure 1 ).

\section{Histopathological Analysis}

The ileum and colon tissues were normal in group SHAM and damaged, to varying degrees, in the other groups. No ulcers or crypt abscesses were observed in any group. There was no capillary or lymphatic dilatation and no mitotic figure was determined in any animal in any of the groups.

Thus, ileum damage was scored from a maximum of 24 points on eight criteria and colon damage from a maximum of 21 on seven criteria. The ileum damage scores were calculated as $3.25 \pm 2.21$ in the SHAM group, $19.20 \pm 2.26$ in the RAD group, $6.90 \pm 1.68$ in the QUER group, and $11.05 \pm 3.01$ in the QUER+RAD group. A statistically significant difference was found between the SHAM group and the RAD group $(p<0.001)$ and between

A
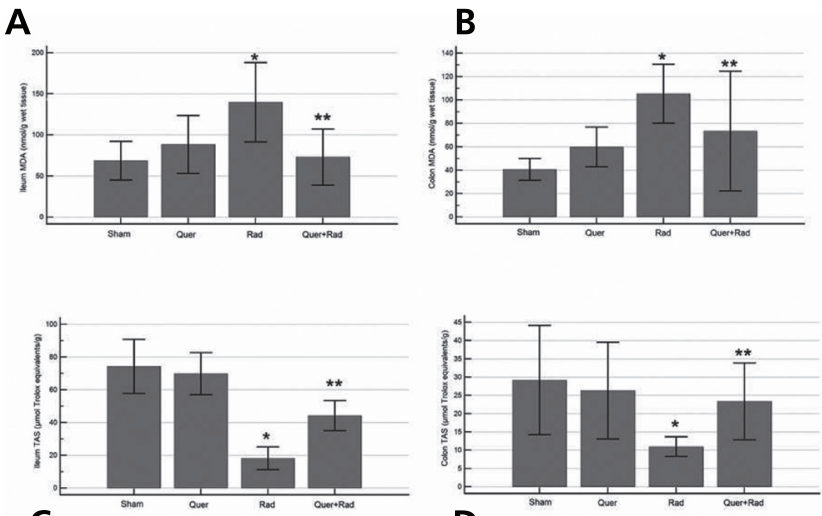

C

Figure 1. Levels of ileum tissue malondialdehyde (A), colon tissue malondialdehyde (B), ileum tissue total antioxidant status (C) and colon tisue total antioxidant status (D) in group's $(n=6)$. Statistically significant with Bonferonni corrected Mann-Whitney $U$ test

${ }^{*} p<0.05$ as compared to group SHAM, ${ }^{*} p<0.05$ as compared to group RAD

MDA: Malondialdehyde, TAS: Total antioxidant status the RAD group and the QUER+RAD group $(p<0.001)$, (Table 3).

The colon damage scores were calculated as $1.70 \pm 1.17$ in the SHAM group, $11.75 \pm 2.14$ in the RAD group, 5.05 \pm 1.39 in the QUER group, and 7.02 \pm 4.34 in the QUER+RAD group. A statistically significant difference was found between the SHAM group and the RAD group $(p<0.001)$ and between the RAD group and the QUER+RAD group ( $p=0.003$ ) (Table 3).

\section{Histopathological Analysis of the Ileum}

Histological changes in the ileum are shown in Figure 2. Statistically significant differences were observed among the four groups with respect to mucosal, submucosal, and muscularis externa thickness values $(p<0.001)$. Between the SHAM group and the RAD group, a statistically significant difference was found in submucosal thickness and the muscularis externa thickness $(p<0.05)$, but there was no statistically significant difference in mucosal thickness ( $p>0.05)$. Between the RAD group and the QUER+RAD group, a statistically significant difference was found in submucosal thickness $(p<0.05)$, but there was no statistically significant difference in muscularis externa thickness or the mucosal thickness ( $p>0.05$ ).

A statistically significant difference was observed in regard to the brush border, villus tip erosion, villus fusion, nuclear changes, fibrinoid changes in the vascular wall, and proliferation in the fibroblasts between the groups $(p<0.001)$, between the SHAM and RAD groups $(p<0.001)$, and between the RAD and QUER+RAD groups $(p<0.001)$.

A statistically significant difference was observed with respect to lymphocytes in the lamina propria in the ileum, polymorphonuclear leukocytes, and eosinophil reaction between the groups $(p<0.001)$, between the SHAM and RAD groups $(p<0.001)$, and between the RAD and QUER+RAD groups $(p<0.001)$.

\section{Histopathological Analysis of the Colon}

Histological changes in the colon are shown in Figure 3. A statistically significant difference was found between the four groups in terms of mucosal, submucosal, and

\begin{tabular}{|c|c|c|c|}
\hline & $\begin{array}{l}\text { lleum } \\
(\mu \mathrm{mol} \text { trolox equivalents } / \mathrm{g})\end{array}$ & $\begin{array}{l}\text { Colon } \\
\text { ( } \mu \mathrm{mol} \text { trolox equivalents } / \mathrm{g})\end{array}$ & $\begin{array}{l}\text { Plasma } \\
\text { (mmol/L trolox equivalent) }\end{array}$ \\
\hline Group SHAM & $73.45(51.90-98.20)^{a, b}$ & $26.15(14.3-56.5)^{a}$ & $0.384(0.370-0.402)^{a, b}$ \\
\hline Group QUER & $71.80(49.0-85.0)^{c, d}$ & $21.75(16.80-50.70)^{c}$ & $0.377(0.354-0.402)^{c}$ \\
\hline Group RAD & $17.80(10.10-27.70)^{a, c, e}$ & $11.30(6.80-14.10)^{a, c, e}$ & $0.332(0.318-0.350)^{a, c, e}$ \\
\hline Group QUER+RAD & $45.4(30.20-56.30)^{\mathrm{b}, \mathrm{d}, \mathrm{e}}$ & $19.45(17.60-43.60)^{\mathrm{e}}$ & $0.355(0.341-0.384)^{b, e}$ \\
\hline$p$ value & $<0.001$ & 0.003 & 0.001 \\
\hline
\end{tabular}




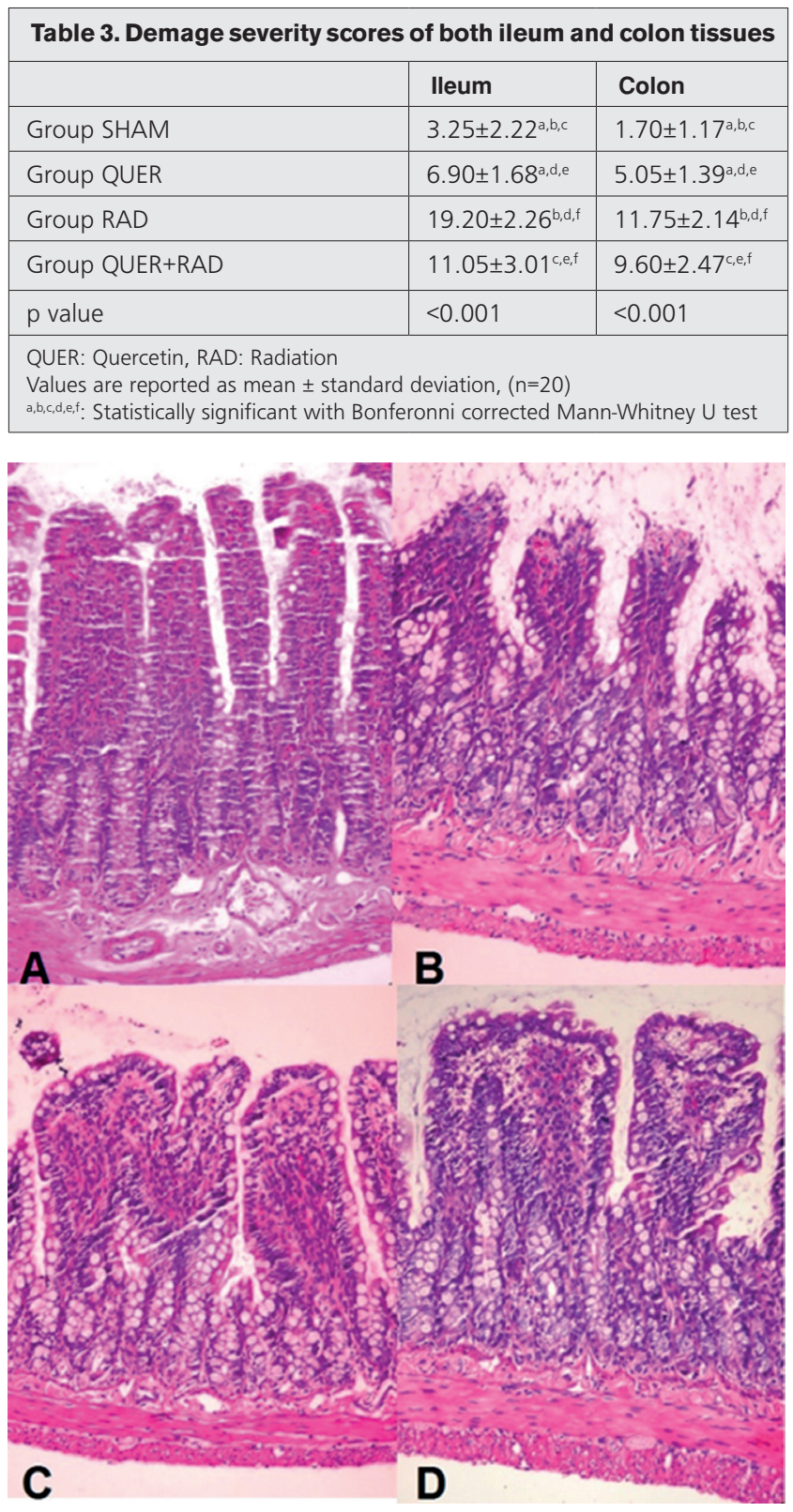

Figure 2. Histopathological examinations of hematoxylin and stain-stained rat tissue: Ileum (x200). A) group SHAM, B) group $R A D, C)$ group QUER and D) group QUER+RAD

muscularis externa thickness values $(p<0.001)$. Between the SHAM group and the RAD group, a statistically significant difference was found in submucosal thickness, muscularis propria thickness, and mucosal thickness $(p<0.05)$. Between the RAD group and the QUER+RAD group, a statistically significant difference was found in submucosal thickness $(p<0.05)$, but there was no statistically significant difference in muscularis propria thickness or mucosal thickness ( $p>0.05$ ).

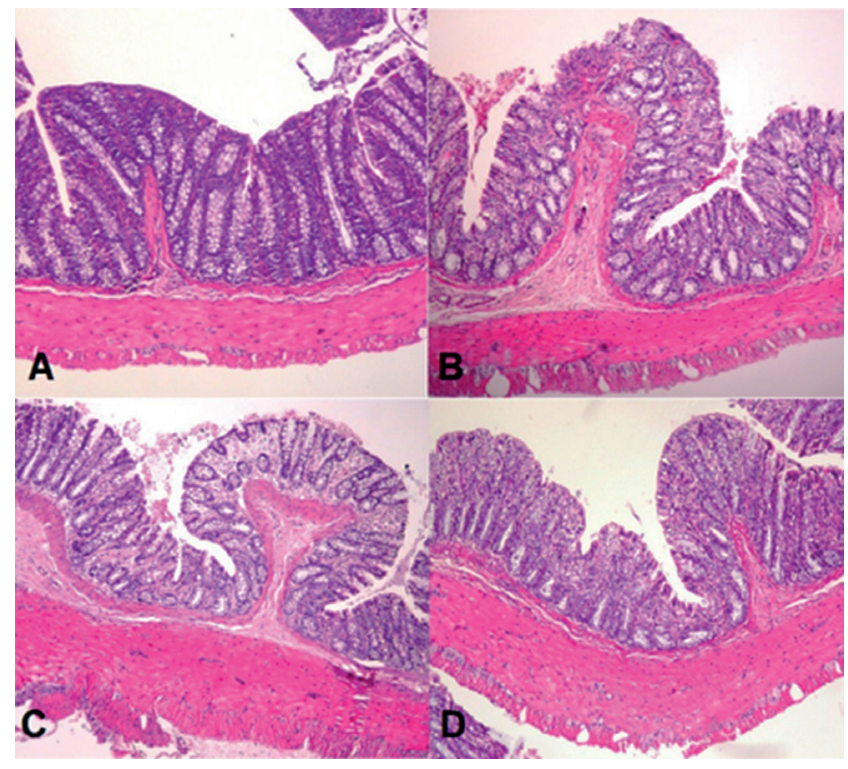

Figure 3. Histopathological examinations of hematoxylin and stain-stained rat tissue: Colon (x200). A) group SHAM, B) group RAD, C) group QUER and D) group QUER+RAD

A statistically significant difference was observed in terms of surface epithelial erosion, nuclear changes, fibrinoid changes in the vascular wall, and proliferation in the fibroblasts between the groups $(p<0.001)$, between the SHAM and RAD groups $(p<0.001)$, and between the RAD and QUER+RAD groups $(p<0.001)$.

A statistically significant difference was observed with regard to lymphocytes in the lamina propria in the colon, polymorphonuclear leukocytes, and eosinophil reactions between the groups $(p<0.001)$, between the SHAM and RAD groups $(p<0.001)$, and between the RAD and QUER+RAD groups $(p<0.001)$.

\section{Discussion}

In this study, significant changes were observed in serum MDA and TAS levels in RT-induced ileum and colon tissues of irradiated rats. The normalisation of elevated tissue and serum MDA levels and the decreased TAS levels following RT may indicate that quercetin improved RT-induced damage in the colon and ileum tissues in rats by reversing the RT-induced lipid peroxidation and antioxidant capacity.

In the treatment of malignancies, RT, chemotherapy, and surgery together have been the most commonly applied methods and have been used with success for 120 years (20). In GIS, urological, and gynaecological malignancies, RT is usually applied to the abdominal and pelvic regions. Upon exposure to radiation in these areas, inflammatory cells are activated and, as a result, there is mucosal damage, destruction of crypt cells, a decrease in the number and size of villous structures, and an increase 
in ulcerative and necrotic areas (6-8). The most important mechanism in the emergence of this damage is an increase in free radicals associated with RT. Oxygen-free radicals cause lipid peroxidation in plasma and organelle membranes, causing an increase in MDA.

By measuring levels of MDA, which is an end-product of lipid peroxidation, an indirect estimation of lipid peroxidation can be made. This measurement is valuable because lipid peroxidation reflects cell death directly (21). During oxidative stress, which is created in association with $\mathrm{RT}$, the anti-oxidant capacity is affected (22). In the current study, MDA and TAS measurements were performed in the ileum and colon tissues and in serum to estimate oxidative stress associated with RT in the ileum and colon tissues.

Several methods have been established, ranging from surgical tests to medical treatments, to reduce or prevent the formation of GIS pathologies caused by RT (23). One of these methods is the use of anti-oxidants. The hypothesis of the present study was that quercetin, as a flavonoid with anti-oxidant effects, could improve the adverse effects of irradiation. In the current study, when the ileum and colon tissue MDA and TAS values and the serum MDA and TAS values were examined, a statistically significant difference was observed between the SHAM group and the groups subjected to RT; this was evaluated as an effect on RT-induced oxidative stress. Furthermore, a statistically significant difference was observed in both the ileum and the colon tissue MDA and TAS values and the serum MDA and TAS values after RT in the rats administered quercetin pre-treatment.

These results were evaluated as an increasing antioxidant effect of quercetin and inhibiting the effects of lipid peroxidation. In several experimental animal models, it has been shown that quercetin has protective effects against tissue damage (24-28). Ozyurt et al. (26) reported that quercetin could provide protection for the kidneys and bladder in radiation-induced toxicity in an animal model. Similarly, in an experimental colitis model, Joo et al. (27) reported that quercetin could ameliorate inflammatory responses by reducing oxidative stress and neutrophil activation.

There is a negative effect on the lives of $~ 50 \%$ of patients receiving pelvic RT because of GIS symptoms (23). This negative effect on quality of life is of a moderate to severe level in $20 \%-40 \%$ of patients, depending on the type of tumour $(23,29)$. In the current study, the DSS was used to assess the severity of the damage created in the ileum and the colon. The DSS described by Howarth et al. (19) in the jejunum and ileum was modified for this purpose. For the DSS calculation, 12 parameters were evaluated for the ileum and 11 parameters for the colon. However, at the end of the study, no ulcers, crypt abscesses, capillary or lymphatic dilation, or mitotic figures were seen in any of the ileum or colon samples in any of the four groups, thus, the DSS calculation included eight histopathological parameters for the ileum and seven for the colon. When the calculated DSSs were examined, there was greater damage in both the ileum and the colon in the rats subjected to RT compared with the SHAM group. In the rats administered quercetin pre-treatment, the RT-induced damage in both ileum and colon tissue was reduced. These findings support the study hypothesis and demonstrate that quercetin reduced and/or could delay morphological tissue damage.

When tissue histopathology was examined in the rats subjected to radiation, no statistically significant change was observed in ileum mucosal thickness or in colon submucosal, muscularis propria, or mucosal thickness, compared with those in the SHAM group. This was thought to be due to the early-stage pathological changes resulting after exposure of the ileum and colon tissue to a single dose of radiation. It was thought that the reason for these changes could have been hyperplasia in the ileum villi and fibroplasia forming in the wall layers with oedema in the colon lamina propria.

In the ileum and colon samples of all four groups, no ulcers, structural changes in crypts, or crypt abscesses were observed. There was no capillary or lymphatic dilatation and no mitotic figure was seen in any group. These results were considered to be due to the radiation regime that was used. A single dose of $10 \mathrm{~Gy}$ of radiation was applied to the rats using a 6-MV linear accelerator at a dose rate of $\sim 1 \mathrm{~Gy} / \mathrm{min}$ with the SAD technique and a $1.0-\mathrm{cm}$ bolus material on the surface. The total radiation dose applied to the related area of patients receiving RT is the most important factor in the emergence of earlyand late-stage findings of GIS damage (30). Other factors in GIS damage include fraction size and the frequency of radiation application (20).

\section{Study Limitations}

In a study by Shukla et al. (31), patients receiving RT between 8:00 and 10:00 A.M. were compared with those receiving RT between 6:00 and 8:00 P.M. It was reported that, in the morning patient group, there were a greater number of cases and more severe diarrhoea. In the current study, the rats were subjected to RT between 8:00 and 9:30 A.M. and because of the weight control of the rats included in the study, diarrhoea was not determined. This was a significant limitation of the study. However, because the RT applied in the study was a single dose and the study was terminated $24 \mathrm{~h}$ after the application of RT, it is not considered to have changed the results. 


\section{Conclusion}

The results of this study confirmed that, in the model of radiation-induced ileitis and colitis in rats, quercetin effectively decreased oxidative stress and inflammatory damage to both ileum and colon tissues.

\section{Ethics}

Ethics Committee Approval: Approval for this study was granted by the Animal Experiments Local Ethics Committee of Zonguldak (Turkey) Bülent Ecevit University Faculty of Medicine (2016-41-06/10).

Informed Consent: Informed Consent was not obtained since the study includes animals only.

Peer-review: Externally and internally peer-reviewed.

\section{Authorship Contributions}

Surgical and Medical Practices: Ö.P., B.G.A. K.K. Concept: Ö.P., K.K. Design: Ö.P., B.G.A. K.K. Data Collection or Processing: Y.B., M.C., Ö.E. Analysis or Interpretation: Ö.P., M.Ç.B. Literature Search: Ö.P., B.G.A. Writing: Ö.P., B.G.A.

Conflict of Interest: No conflict of interest was declared by the authors.

Financial Disclosure: The authors declared that this study received no financial support.

\section{References}

1. Guney $Y$, Hicsonmez A, Uluoglu C, et al. Melatonin prevents inflammation and oxidative stress caused by abdominopelvic and total body irradiation of rat small intestine. Braz J Med Biol Res 2007; 40:1305-14.

2. Seal M, Naito $Y$, Barreto R, Lorenzetti A, Safran P, Marotta F. Experimental radiotherapy-induced enteritis: a probiotic interventional study. J Dig Dis 2007;8:143-7.

3. Ki Y, Kim W. The effect of probiotics for preventing radiationinduced morphological changes in intestinal mucosa of rats. J Korean Med Sci 2014;29:1372-8.

4. Bismar MM, Sinicrope FA. Radiation enteritis. Curr Gastroenterol Rep 2002;4:361-5.

5. Odabasi M, Gokdemir S, Muftuoglu T, Aktekin A, Saglam A, Aker F. Prophylactic and therapeutic effects of oral budesonide for acute radiation-induced enteritis and colitis in rats. Int J Clin Exp Med 2014;7:940-6.

6. Cagin YF, Parlakpinar H, Polat A, et al. The protective effects of apocynin on ionizing radiation-induced intestinal damage in rats. Drug Dev Ind Pharm 2016;42:317-24.

7. Erbil Y, Dibekoglu C, Turkoglu U, et al. Nitric oxide and radiation enteritis. Eur J Surg 1998;164:863-8.

8. Becciolini A, Balzi M, Fabbrica D, Potten CS. The effects of irradiation at different times of the day on rat intestinal goblet cells. Cell Prolif 1997;30:161-70.

9. Akpolat M, Gulle K, Topcu-Tarladacalisir Y, et al. Protection by $L$-carnitine against radiation-induced ileal mucosal injury in the rat: pattern of oxidative stress, apoptosis and cytokines. Int J Radiat Biol 2013;89:732-40.

10. Carroll MP, Zera RT, Roberts JC, et al. Efficacy of radioprotective agents in preventing small and large bowel radiation injury. Dis Colon Rectum 1995;38:716-22.

11. Srinivasan V, Weiss JF, Kumar S. Radioprotection by misoprostol (PGE1 methyl analog) in combination with vitamin E, selenomethionine and WR-3689794. Adv Exp Med Biol 1997;400B:791-7.

12. Yamamoto Y, Gaynor RB. Therapeutic potential of inhibition of the NF-kappaB pathway in the treatment of inflammation and cancer. J Clin Invest 2001;107:135-42.

13. Cazarolli LH, Zanatta L, Alberton EH, et al. Flavonoids: prospective drug candidates. Mini Rev Med Chem 2008;8:1429-40.

14. Gomes A, Couto D, Alves A, et al. Trihydroxyflavones with antioxidant and anti-inflammatory efficacy. Biofactors 2012;38:378-86.

15. Pan MH, Lai CS, Ho CT. Anti-inflammatory activity of natural dietary flavonoids. Food Funct 2010;1:15-31.

16. Dodda D, Chhajed R, Mishra J. Protective effect of quercetin against acetic acid induced inflammatory bowel disease (IBD) like symptoms in rats: possible morphological and biochemical alterations. Pharmacol Rep 2014;66:169-73.

17. Ishige K, Schubert D, Sagara Y. Flavonoids protect neuronal cells from oxidative stress by three distinct mechanisms. Free Radic Biol Med 2001;30:433-46.

18. Gultekin FA, Bakkal BH, Guven B, et al. Effects of ozone oxidative preconditioning on radiation-induced organ damage in rats. J Radiat Res 2013;54:36-44.

19. Howarth GS, Fraser R, Frisby CL, Schirmer MB, Yeoh EK. Effects of insulin-like growth factor-I administration on radiation enteritis in rats. Scand J Gastroenterol 1997;32:1118-24.

20. Theis VS, Sripadam R, Ramani V, Lal S. Chronic radiation enteritis. Clin Oncol (R Coll Radiol) 2010;22:70-83.

21. Vrndic OB, Radivojevic SD, Jovanovic MD, Djukic SM, Teodorovic LC, Simonovic ST. Oxidative stress in patients with differentiated thyroid cancer: early effects of radioiodine therapy. Indian J Biochem Biophys 2014;51:223-9.

22. Khalil Arjmandi M, Moslemi D, Sadati Zarrini A, et al. Pre and post radiotherapy serum oxidant/antioxidant status in breast cancer patients: Impact of age, BMI and clinical stage of the disease. Rep Pract Oncol Radiothe 2016;21:141-8.

23. Stacey R, Green JT. Radiation-induced small bowel disease: latest developments and clinical guidance. Ther Adv Chronic Dis 2014;5:15-29.

24. Liu C-M, Zheng Y-L, Lu J, Zhang Z-F, et al. Quercetin protects rat liver against lead-induced oxidative stress and apoptosis. Environ Toxicol Pharmacol 2010;29:158-66.

25. Abdel-Raheem IT, Abdel-Ghany AA, Mohamed GA. Protective effect of quercetin against gentamicin-induced nephrotoxicity in rats. Biol Pharm Bull 2009;32:61-7. 
26. Ozyurt H, Cevik O, Ozgen Z, et al. Quercetin protects radiation-induced DNA damage and apoptosis in kidney and bladder tissues of rats. Free Radic Res 2014;48:124755.

27. Joo M, Kim HS, Kwon TH, et al. Anti-inflammatory Effects of Flavonoids on TNBS-induced Colitis of Rats. Korean J Physiol Pharmacol 2015;19:43-50.

28. Guazelli CFS, Fattori V, Colombo BB, et al. Quercetin-loaded microcapsules ameliorate experimental colitis in mice by anti-inflammatory and antioxidant mechanisms. J Nat Prod 2013;76:200-8.
29. Andreyev J. Gastrointestinal symptoms after pelvic radiotherapy: a new understanding to improve management of symptomatic patients. Lancet Oncol 2007;8:1007-17.

30. Letschert JG, Lebesque JV, de Boer RW, Hart AA, Bartelink H. Dose-volume correlation in radiation-related late small-bowel complications: a clinical study. Radiother Oncol 1990;18:30720.

31. Shukla P, Gupta D, Bisht SS, et al. Circadian variation in radiation-induced intestinal mucositis in patients with cervical carcinoma. Cancer 2010;116:2031-5. 